\title{
In vitro effect of different cytokinin types (BAP, TDZ) on two different Ocimum basilicum cultivars explants
}

\author{
Enkhbileg, E. ${ }^{1}$, Fári, M. G. ${ }^{2}$ \& Kurucz, E. ${ }^{1}$ \\ ${ }^{1}$ University of Debrecen, Faculty of Agricultural and Food Sciences and Environmental Management, Institute of Plant Sciences, \\ 4032 Debrecen, Böszörményi út 138, Hungary \\ ${ }^{2}$ University of Debrecen, Faculty of Agricultural and Food Sciences and Environmental Management, Department of Botany, \\ Biotechnology and Plant Physiology \\ 4032 Debrecen, Böszörményi út 138, Hungary \\ Author for correspondence: era.kurucz@gmail.com
}

\begin{abstract}
Summary: Ocimum basilicum L. (sweet basil) is an economically and ethnobotanically important aromatic, medicinal, ornamental and culinary herb, with a very wide gene pool, that is sensitive to cold and prone to several plant pathogens that can demolish harvest and lessen yield. In this research, the effects of BAP (6-Benzylaminopurine) and TDZ (Thidiazuron) on different genotypes for in vitro cloning were determined, in order to provide a detailed protocol guide concerning Ocimum basilicum L. propagation. The results from the $O$. basilicum seed propagations revealed that the best condition for the secondary shoot growth is with $5.0 \mathrm{mg} / \mathrm{l} \mathrm{TDZ}$ or $1.5 \mathrm{mg} / \mathrm{l} \mathrm{BAP}$ on all types of explants except the root, the secondary root growth can be obtained on all types explant with any BAP concentration and all cytokinins can induce callus on all types of explants. On the whole, it shows that multiple secondary shoot induction and regeneration in Ocimum basilicum L. is regulated by appropriate cytokinin concentration.
\end{abstract}

Enkhbileg, E., Fári, M. G., Kurucz, E. (2019): In vitro effect of different cytokinin types (BAP, TDZ) on two different Ocimum basilicum cultivars explants. International Journal of Horticultural Science 2019(3-4): 15-20. https://doi.org/10.31421/IJHS/25/3$4 / 3930$

Key words: sweet basil, Ocimum basilicum L., In vitro, cytokinin effect, BAP (6-Benzylaminopurine), TDZ (Thidiazuron)

\section{Introduction}

Nowadays, in order to defend our physical and mental health, the plant originated products gain more and more importance in our lives. Ocimum basilicum L. (sweet basil) is an economically and ethnobotanically important aromatic medicinal, ornamental and culinary herb of the family Lamiaceae (mints). It originates from the tropical and subtropical regions of Asia, Africa and Central and South America (Darrah 1980; Paton et al., 1999). The Ocimum L. genus includes more than 150 species of annual and perennial herbs and shrubs, from which, $O$. africanum Lour. (syn. $O$. citriodorum Vis.), O. americanum L. (syn. O. canum Sims.), O. basilicum L., O. gratissimum L., O. minimum L., and $O$. tenuiflorum L. (syn. O. sanctum L.) species are cultivated the most, in different parts of the world, including France, Hungary, Greece, Russia, Indonesia, Israel, Egypt, Morocco, and the United States (Srivastava, 1980; Kisgeci-Adamovic, 1994; Adamovic, 2012).

Most of the taxa are essentially based on leaf color and morphology, which is normally regulated by environmental conditions. The generalized morphological appearance of sweet basil is up to $35 \mathrm{~cm}$ high, oval, toothed or whole, with up to $8 \mathrm{~cm}$ long leaves. The flowers are white or purple, approximately $1 \mathrm{~cm}$ long and are carried in simple terminal racemes. Some varieties have partially red or wholly purple leaves (Vaughan-Geissler, 1997). Solely the leaves of Ocimum basilicum, and its close relatives have noticeably diverse variations in size, shape and colour. They vary from tiny and liniform to huge and round, and from yellow-green to greygreen, to red or to nearly black.
Ocimum L. species are used in the food, perfumery and medicinal industries, as a flavoring agent, aroma mix and raw material respectively (Simon et al., 1990).

The whole plant is utilizable in fresh, frozen, dried and oil extract forms, but the most useful parts of the basil are its seeds and leaves. The leaves are the source of aromatic compounds and essential oils, which consist of phenolic compounds (Simon et al., 1990; Phippen-Simon, 2000), polyphenols such as anthocyanins and flavonoids (Phippen-Simon, 1998), and many other natural constituents that are biologically active products with potent properties against insects (Murugan et al., 2006), nematodes (Simon et al., 1999), bacteria (Saha et al., 2013), fungi (Saggiorato et al., 2012), hematotoxicities (Saha et al., 2012), and oxidant activities (Jayasinghe et al., 2003). In medicine, these properties are traditionally used for treating headache, cough, diarrhea, constipation, kidney malfunction, worms, warts, and salmonellosis (Chopra et al., 1994; Simon et al., 1999).

Micropropagation is affected by a number of determinants such as genotype of explant, culture medium (Molassiotis et al., 2003), and plant growth regulators (Nowak et al., 2004; Ruzic et al., 2003; Ruzic et al., 2008). The cytokinin hormone is considered one of the most important determinants in plant tissue culture, particularly in the proliferation stage.

By discovering their ability to induce plant cell division, the cytokinins were introduced during the 1950s (Miller et al., 1955). Soon after that, the auxin \pm cytokinin hypothesis of plant morphogenesis was formed by Skoog \& Miller (1957), which predicted that cytokinin, together with auxin, is fundamentally 
essential in the morphogenesis of plants, since they have a visibly strong effect on the formation of shoots and roots and their relative development and growth.

In numerous reports, researchers used BAP as a synthetic cytokinin, combined with suitable auxins, for example, for the micropropagation of nut fruits (George et al., 2008; Ruzic et al., 2008). Moreover, in case of Prunus species' micropropagation, BA, BAP and TDZ are frequently used as cytokinin growth enhancers, since they were proved to be applicable in the in vitro proliferation step (DurkovicMisalova, 2008). Especially the adenine type of cytokinins at high concentrations are often necessary for growth and differentiation of Prunus species (Sutter, 1996). Ruzic et al. (2008) addressed that BA and TDZ are the mainly applied cytokinins.

Information concerning the biological functions of cytokinins have mostly been studied from the visible results of exogenous application or endogenous hormone level enhancement (Klee-Lanahan, 1995; Schmuelling et al., 1999).

In distinct developmental processes like branching, root growth, leaf senescence, chloroplast development and control of apical dominance in the shoot, an inhibitory or stimulatory function has been tied to cytokinins by many investigators (Mok, 1994)

There are a number of significant clusters of evidence displaying that for a maximally prosperous proliferation, determining the appropriate type and concentration of growth regulators is absolutely necessary. (Ruzic, 2008). The cytokinin's ability to promote plants' cell division, shoot multiplication and axillary bud formation, is universally proved.

According to Dobránszki \& Teixeira da Silva (2010), shoot induction and formation of plants is influenced by cytokinin, because they stimulate the initiation and activity of axillary meristems.

In the present study, we exhibited an experiment to focus solely on the functions and influence of cytokinin on the secondary shoot, secondary root and calli formation using two different genotypes of Ocimum basilicum L.

\section{Materials and methods}

\section{Plant material}

The seeds of two commercial Hungarian Ocimum basilicum L. varieties (purple/bíborgömb, green/zöldgömb) were surface decontaminated with $70 \%$ ethanol $(20 \mathrm{sec})$ and $3 \%(\mathrm{w} / \mathrm{v})$ $\mathrm{CaOCl}(15 \mathrm{~min})$ and thoroughly rinsed with sterile distilled water (3-5 $\mathrm{min})$ to remove any trace of sterilant.

\section{Culture medium}

Following the sterilization, seeds were cultured on MS medium (Murashige \& Skoog, 1962) with 1.0\% sucrose and $0.65 \%$ agar for germination. The media has also provided 100 $\mathrm{mg} / \mathrm{L}$ cefotaxim in order to reduce contaminations (Figure 1).

All of the plants parts were used for plant regeneration, the explants were isolated from 12-14 days old in vitro grown seedlings and then inoculated on MS medium having 1 and 5 $\mathrm{mg} / \mathrm{L}$ Thidiazuron (TDZ) or 05-2 mg/L 6-Benzylaminopurin (BAP) (Table 1). Culture medium was also provided with 0,1 $\mathrm{g} / \mathrm{L}$ Casein hydrolisate. The medium without growth regulator were the control. All culture media were autoclaved for $21 \mathrm{~min}$ at $1.6 \mathrm{~kg} \mathrm{~cm}$. The $\mathrm{pH}$ of all culture medium was adjusted to 5.6-5.8 using $1 \mathrm{~N}$ citic acid or $1 \mathrm{~N} \mathrm{KOH}$ after adding BAP or TDZ growth regulators. All cultures were grown at $25 \pm 2^{\circ} \mathrm{C}$ with a 16/8-h (light/dark) photoperiod using cool-white fluorescent lamps with light intensity of $25 \mu \mathrm{mol} \mathrm{m} \mathrm{m}^{-2} \mathrm{~s}^{-1}$.

The experiment was run in triplicate containing 4 explants from each variety $(3 \times 2 \times 4 \times 10=240$ explants). The explants were excised, cut into single nodal segments and further multiplied for induction of multiple shoots, roots and calli (Figure 2). The frequency with which explants produced calli, secondary shoots and roots, the number of shoots per explant were recorded after 4 weeks of culture. The explants that developed secondary shoots and roots were transplanted into fresh medium of the same composition for further development.

\section{Statistical analysis}

All data are represented as mean \pm SE, Descriptive statistical methods (sum, mean, standard deviation) and oneway ANOVA were used to determine the impact of treatments. Data were evaluated with Microsoft Excel and SPSS 11.0. The significant differences between each treatment were determined with Tukey's test at the probability level of 5\%.

\section{Results and discussion}

One of the key influencers of morphogenesis is the medium composition. Murashige\&Skoog basal medium has been commonly used for plant micropropagation. Based on the findings of many researchers, for in vitro proliferation, cytokinins must be included in the media (Sutter, 1996; Dobranszki-Teixeira Da Silva, 2010). Depending on the kind of culture medium, the variety of plant and the age of explants, the effects of cytokinins on micropropagation can differ (Thorpe et al., 2008). In case of $O$. basilicum, the proliferation rate of micropropagation process has been strongly influenced by the culture medium and the supplemented cytokinins.

There have been many reports about TDZ application for callus induction on various explants from a number of recalcitrant species including medicinal plants (Mithila et al., 2003). Aasim et al., (2010) and Karatas et al., (2013) reported $100.0 \%$ callus induction at different concentration of TDZIBA on cotyledonary node explant cultured in fenugreek and dwarf hygro respectively. Conflictingly, Basalma et al., (2008) reported suppressed callus induced by TDZ using hypocotyl and cotyledon explants of Astragalus cicer.

During this experiment, all of the used plant growth regulators initiated callus proliferation and almost all of the explants produced callus (Figure 3).

According to our research, the influence of hormones on shoot regeneration has been much disputed. Some researchers reported that TDZ is more effective than BAP (Perez-Tornero et al., 2000; Bhagvat \& Lane, 2004; Matt \& Jehle, 2005; Espinosa et al., 2004; Canli \& Tian, 2008), while others have reported that BAP is more effective than TDZ (TANG et al., 2002; RUZIC, 2008). These conflicting results are assumed to be ascribed to the utilizatin of different species along with the plausible effects of different genotypes.

Moreover, Sahin-Demirbag et al. (2008) reported to use TDZ at relatively low concentration for in vitro shoot regeneration. However, Phippen \& Simon (2000) and Ekmekci \& Aasim (2014) found that for maximum callus and shoot 

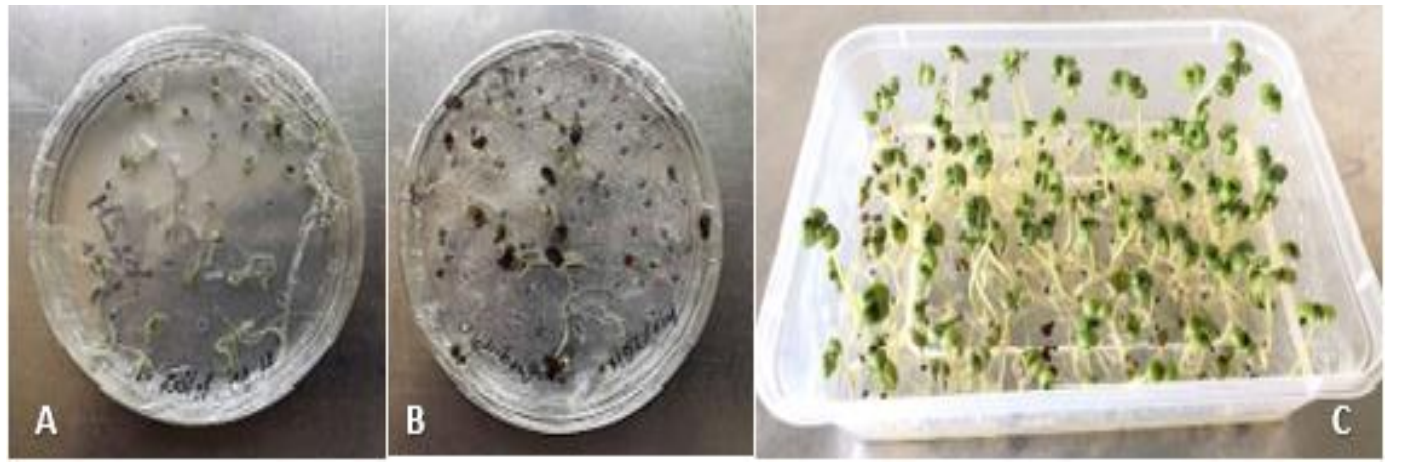

Figure 1. Ocimum basilicum L. seed culture.

A: O.b green, B: O.b purple, C: 12-14 days old seedlings

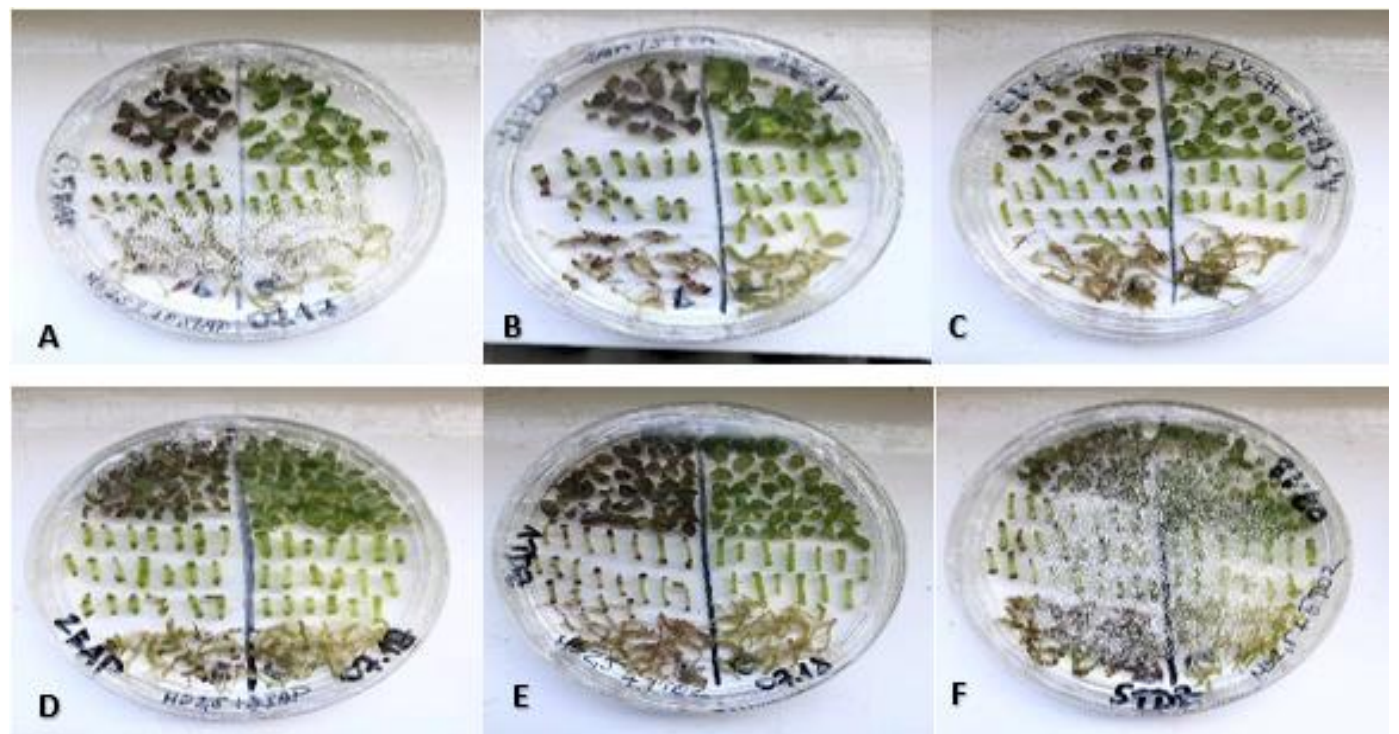

Figure 2. Explants on media containing different hormones.

A: 0.5BAP, B: 1BAP, C: 1.5BAP D: 2BAP E: 1TDZ, F: 5TDZ
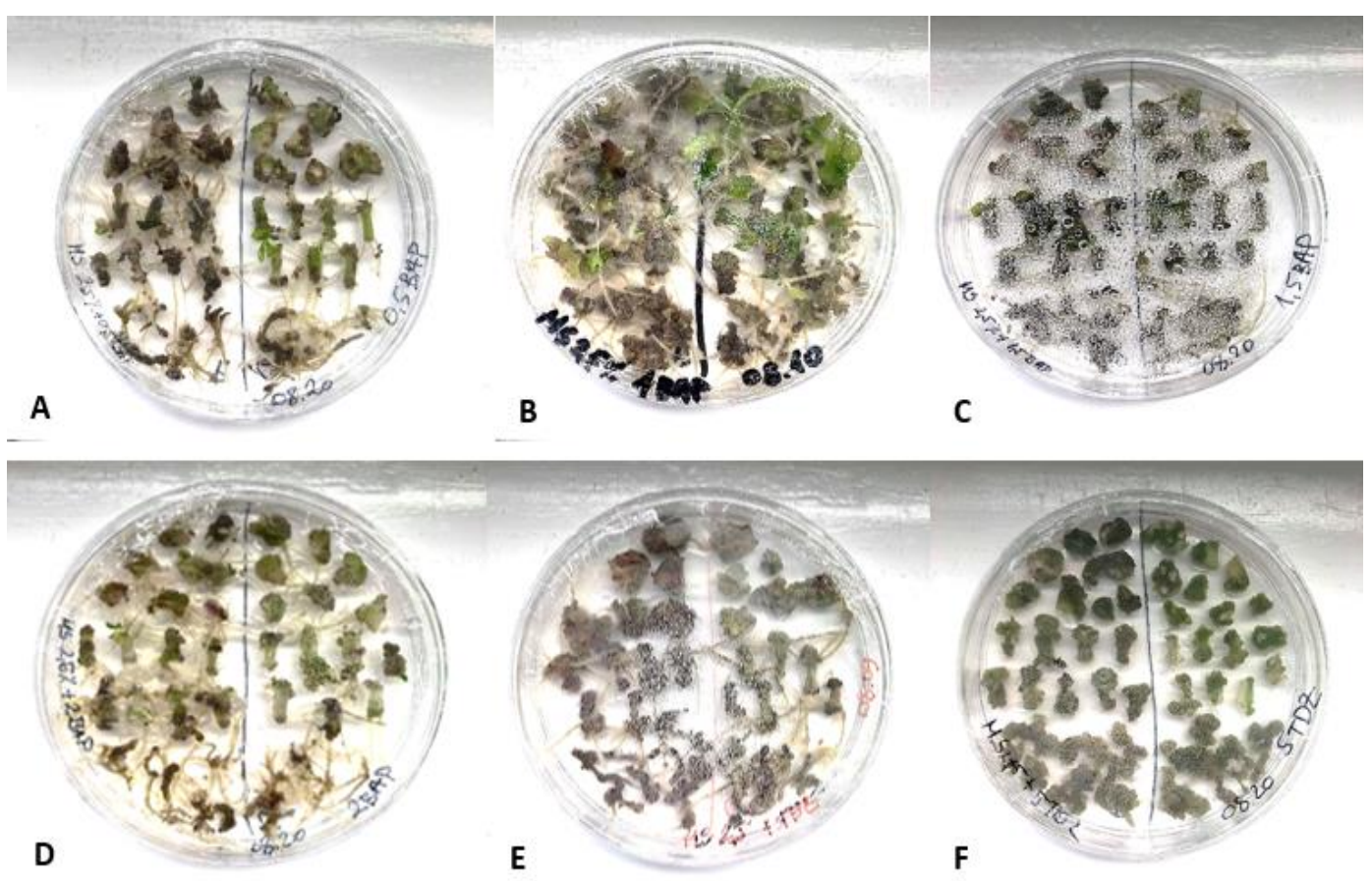

Figure 3. 4 weeks old explants on media containing different hormones.

A: 0.5BAP, B: 1BAP, C: 1.5BAP D: 2BAP E: 1TDZ, F: 5TDZ 


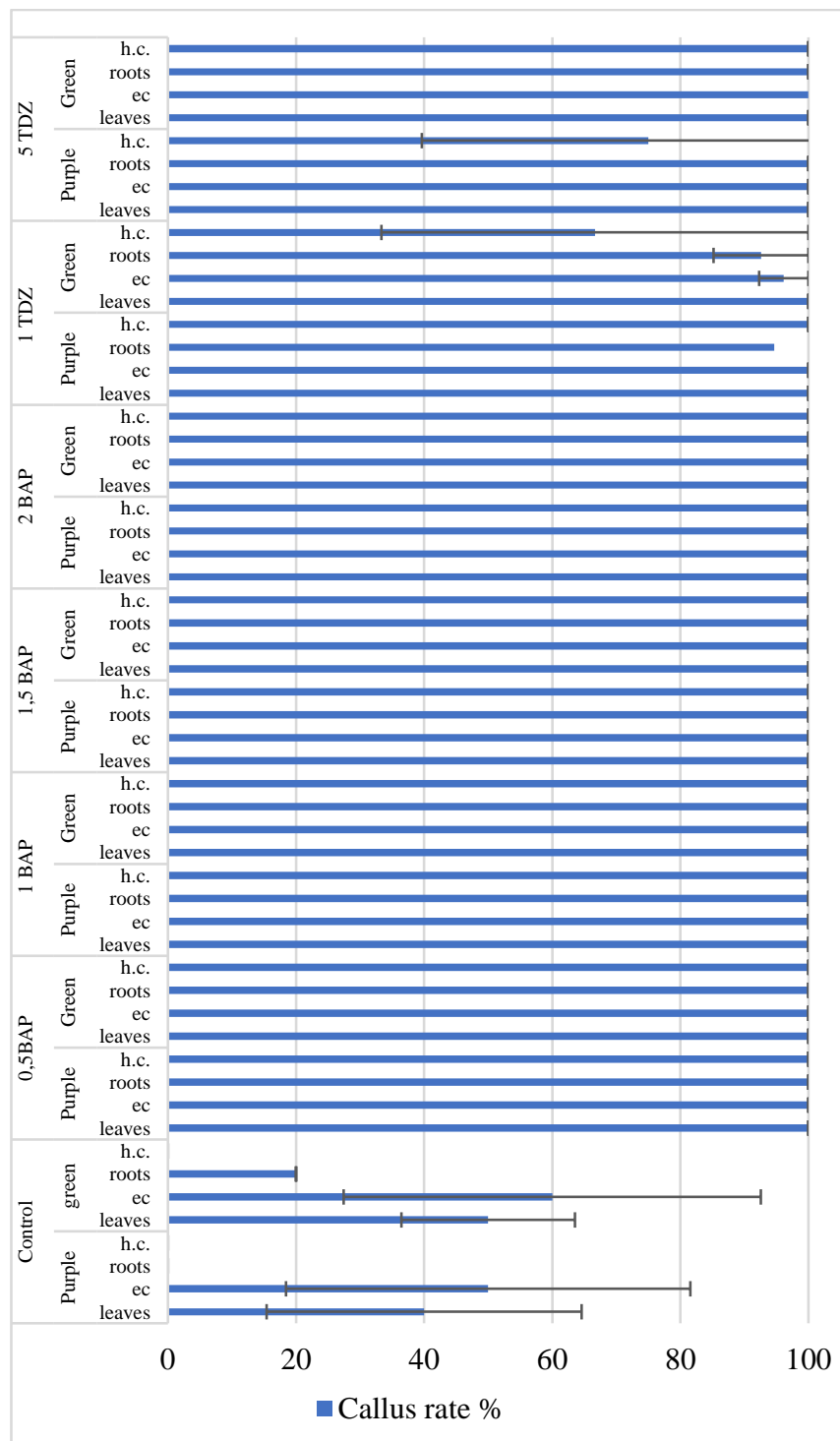

Figure 4. Rooting percentage of different explants of different O. basilicum varieties

h.c: hypocotyl, e.c: epycotyl

induction, on numerous basil cultivars, higher concentration of TDZ $(16.8 \mu \mathrm{M}$ or $4 \mathrm{~m} \mathrm{~g} / \mathrm{l})$ is required. Consequently, in our experiment, TDZ was used singly at relatively higher concentrations ( 1 and $5 \mathrm{mg} / \mathrm{l}$ ) for in vitro shoot regeneration of four different types of explants of two distinct Ocimum basilicum genotypes (Figure 4).

The results on shoot and root regeneration frequency demostrated reaction of explant type to BAP concentration as shoot regeneration of root explant was found negligible to growth regulators.

Without cytokinin supplements on MS medium, even after 6 weeks of inoculation, the explants could not produce a single secondary shoot. With cytokinin supplements at different concentrations, however, a great variation in the generation of secondary roots, shoots and number of shoots per explant have been observed.

In the current examination, epycotyl and hypocotyl explants actively exhibited sensitivity to growth regulators and TDZ at higher concentrations increased the shoot regeneration frequency (Figure 5). We obtained maximum shoot regeneration at $5.0 \mathrm{mg} / \mathrm{l} \mathrm{TDZ}$ using cotyledonary node of purple cultivar of $O$. basilicum varieties. By these findings, we confirmed the results reported by many researchers, including

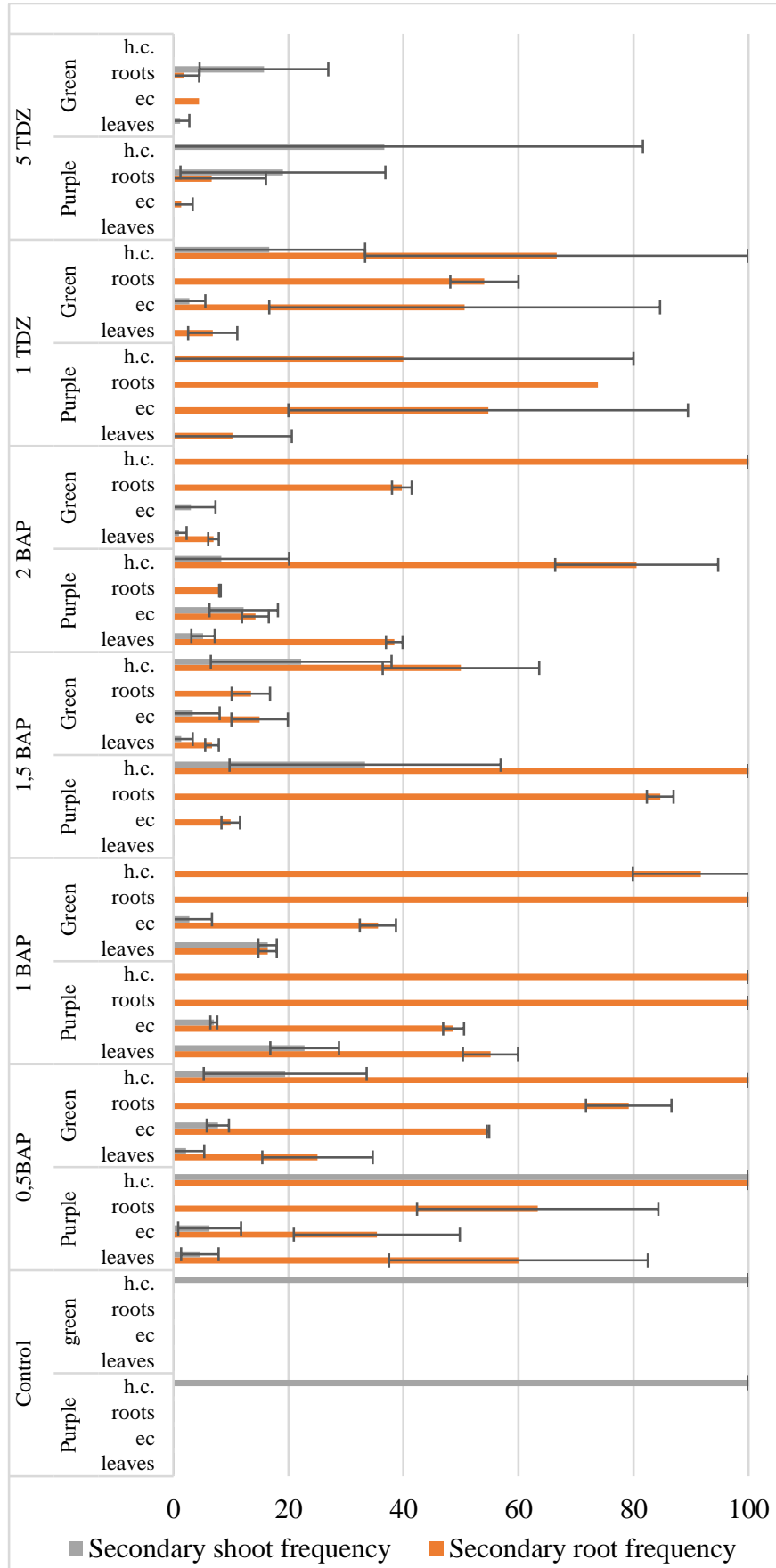

Figure 5. The secondary root and shoot frequency of different explants of h.c: hypocotyl, e.c: epycotyl different $O$. basilicum varieties.

Perez-Tornero et al. (2000), Bhagvat-Lane (2004), Espinosa et al. (2004), and Canli-Tian (2008), which suggested that TDZ is more suitable for shoot multiplication. In case of BAP application, the $1.5 \mathrm{mg} / \mathrm{l}$ was the most effective in both genotypes, which also agrees with those of Thorpe et al. (2008) that reported BAP is required at low concentrations ranging from 0.5 to $2.5 \mathrm{mg} / \mathrm{l}$.

From the result of secondary root regeneration, we found that any concentration of BAP could induce the secondary root proliferation mainly in hypocotyl and root explants, contrary to the previous studies on the effect of cytokinin (Figure 6). This phenomenon could be due to the interaction between the endogenous hormones and the exogenous additive plant growth regulators, or the other secondary metabolic effect to the hormone sensitivity, or the reaction of the cells. 


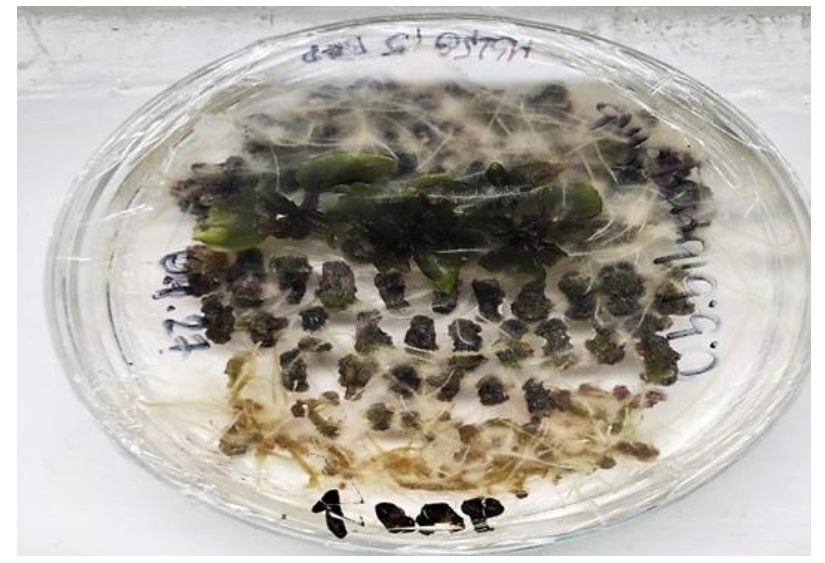

Figure 6. Secondary root regeneration on all types of explants in medium supplemented with 1 BAP

\begin{tabular}{|lrllll|}
\hline \multicolumn{2}{c}{ Salts } & \multicolumn{2}{c}{ Carbohydrides } & \multicolumn{2}{c|}{ Cytokinin } \\
MS & 4.4 & Sacharose & $2.5 \%$ & BAP & 0 \\
MS & 4.4 & Sacharose & $2.5 \%$ & BAP & 0.5 \\
MS & 4.4 & Sacharose & $2.5 \%$ & BAP & 1 \\
MS & 4.4 & Sacharose & $2.5 \%$ & BAP & 1.5 \\
MS & 4.4 & Sacharose & $2.5 \%$ & BAP & 2 \\
MS & 4.4 & Sacharose & $2.5 \%$ & TDZ & 1 \\
MS & 4.4 & Sacharose & $2.5 \%$ & TDZ & 5 \\
\hline
\end{tabular}

Table 1. The regeneration media for $O$. basilicum $\mathrm{L}$. in vitro cloning/propagation

Moreover, we observed differences between the genotypes, but these differentations require further studies to determine the genetic background of hormone sensitivity.

On the whole, the results of the current experiment indicate that MS medium with TDZ were more efficient than with BAP for in vitro propagation of Ocimum basilicum varieties.

\section{Conclusions}

The in vitro propagation results revealed significantly different responses of explants to different BAP and TDZ concentration on shoot regeneration frequency, root regeneration frequency and callus induction. However, regardless of the genotype and medium concentrations, the shoot regeneration of root explant was found insignificant to growth regulators.

Regardless of cytokinin concentration in the culture medium, the callus induction frequencies were reported a $100 \%$ for all types of explants. Higher concentration of TDZ induced more shoot regeneration frequency, showing the maximum shoot regeneration on the explants at $5.0 \mathrm{mg} / \mathrm{l} \mathrm{TDZ}$ using cotyledonary node of purple cultivar of $O$. basilicum varieties.

The concentration of BAP showed the most effective shoot regeneration at $1.5 \mathrm{mg} / \mathrm{l}$ in both genotypes. Additionally, we observed differences between the genotypes, but these differentiations require further studies to determine the genetic background of hormone sensitivity.

The most extraordinary finding of this experiment was that any concentration of BAP could induce the secondary root proliferation in all types of explants. This phenomenon could be due to the interaction between the endogenous hormones and the exogenous additive plant growth regulators, or the other secondary metabolic effect to the hormone sensitivity or the reaction of the cells. To answer this question, further studies and examinations are needed.

\section{References}

Aasim, M., Hussain, N., Umer, E. M., Zubair, M., Hussain, S. B., Saeed, S., Rafique, T. S., Sancak, C. (2010): In vitro shoot regeneration of fenugreek (Trigonella foenum-graecum L.) using different cytokinins. Afr. J. Biotechnol. 9(42): 71747179. https://doi.org/10.5251/abjna. 2013.4.3.243.251

Adamović, S. (2012b): Yield and quality of basil grown as a second crop under organic and conventional conditions. XVI International EcoConference 2012, (pp. 315-319). Novi Sad, Serbia.

Basalma, D., Uranbey, S., Gurlek, D., Ozcan, S. (2008): TDZ induced plant regeneration in Astragalus cicer L. Afr. J. Biotechnol. 7(8): 955-959. Available online at http://www.academicjournals.org/AJB,ISSN 1684-5315 C 2008 Academic Journals

Bhagwat, B., Lane, W. D. (2004): In vitro shoot regeneration from leaves of sweet cherry (Prunus avium) 'Lapins' and'Sweetheart'. Plant Cell, Tissue and Organ Culture, 78(2), $173-$ 181. https://doi.org/10.1023/B:TICU. 0000022552. 12449.71.

Canli, F. A, Tian, L. (2008): In vitro shoot regeneration from storedmature cotyledons of sweet cherry (Prunus avium L.) cultivars. Sci Hortic 116(1):34-40 DOI:10.1016/ j.scienta.2007.10.023

Chopra, R. N., Nayar, S. L., Chopra, I. C. (1994): Glossary of Indian Medicinal Plants (Including the Supplement). Council of Scientific and Industrial Research. New Delhi, India.

Darrah, H. (1980): The cultivated basils. Thomas Buckeye, Independence, MO.

Dobránszki, J., Teixeira da Silva, J. A. (2010): Micropropagation of Apple - A Review. Biotechnology Advances, 28. 462-488.https://doi.org/10.1016/j.biotechadv. 2010.02.008.

Ďurkovič, J., Mišalová, A. (2008): Micropropagation of temperate noble hardwoods: an overview. Functional Plant Science and Biotechnology, 2(1), 1-9. https://www.researchgate.net/profile/Jaroslav_Durkovic/public ation/257536571_Micropropagation_of_Temperate_Noble_Ha rdwoods_An_Overview/links/Odeec525651f6703f4000000.pdf

Ekmekci, H., Aasim, M. (2014): In vitro plant regeneration of Turkish sweet basil (Ocimum basilicum L.). J Anim Plant Sci, 24: 1758-1765 p. ISSN: 1018-7081 http://www.thejaps. org.pk/docs/v-24-6/27.pdf

Espinosa, A. C., Pijut, P. M., Michler, C. H. (2006): Adventitious shoot regeneration and rooting of Prunus serotina in vitro cultures. HortScience 41(1):193-201. https://www.fs.usda.gov/treesearch/pubs/13875

George, E. F., Hall, M. A., De Klerk, G. J. (2008): Plant Tissue Culture Procedure - Background. Plant Propagation by Tissue Culture. https://doi.org/10.1007/978-1-4020-5005-3_1.

Jayasinghe, C., Gotoh, N., Aoki, T., Wada, S. (2003): Phenolics composition and antioxidant activity of sweet basil (Ocimum basilicum L.). J. Agric. Food Chem. 51: 4442-4449. https://doi.org/10.1021/jf034269o

Karatas, M., Aasim, M., Çınar, A., Dogan, M. (2013): Adventitous shoot regeneration from leaf explant of dwarf hygro (Hygrophila polysperma (Roxb.) T. Anderson). ScientificWorld J. http://dx.doi.org/10.1155/2013/680425 
Kišgeci, J., Adamović, D. (1994): Gajenje lekovitog bilja. Beograd: Nolit. 185 p

Klee, H. J., Lanahan, M. B. (1995): Plant Hormones: Physiology, Biochemistry and Molecular Biology, ed. Davies, P. J., Kluwer, Dordrecht, the Netherlands, 340-353. https://doi.org/ 10.1007/978-94-011-0473-9

Matt, A., Jehle, J. A. (2005): In vitro plant regeneration from leaves and internode sections of sweet cherry cultivars (Prunus avium L.) Plant Cell Rep. 24: 468-476. https://doi.org/10. 1007/s00299-005-0964-6

Miller, C .O., Skoog, F. S., Okomura, M. H., Von Saltza, H., Strong, F. M. (1955): Kinetin, a cell division factor from deoxyribonucleic acid. In: J. Am. Chem. Soc. 77: 1392-1393. https://doi.org/ 10.1021/ja01610a105

Mithila, J., Hall, J. C., Victor, J. M. R., Saxena, P. K. (2003): Thidiazuron induces shoot organogenesis at low concentrations and somatic embryogenesis at high concentrations on leaf and petiole explants of African violet (Saintpaulia ionantha Wendl.). Plant Cell Rep. 21(5): 408-414. https://doi.org/10.1007/s00299-002-0544-y

Mok, M. C. (1994): Cytokinins: Chemistry, Activity and Function, eds. Mok, D. W. S. \& Mok, M. C., CRC, Boca Raton, FL, 155-166.

Molassiotis, A., Dimassi, K., Therios, I., Diamantidis, G. (2003): Fe-EDDHA Promotes Rooting of Rootstock GF-677 (Prunus amygdalus $\times P$. persica) Explants in vitro Biol. Plantarum. 47: 141-144. https://doi.org/10.1023/A: 1027309705022

Murugan, K., Murugan, P., Noortheen, A. (2006): Larvicidal and repellent potential of Albizzia amara Boivin and Ocimum basilicum Linn against dengue vector, Aedes aegypti (Insecta: Diptera: Culicidae). Bioresour. Technol. 98: 198-201. https://doi.org/10.1016/j.biortech.2005.12.009

Nowak, B., Miczyn'ski, K., Hudy, L. (2004): Plant Cell, Tissue Organ Cult. 76: 255-260.

Paton, A., Harley, M. R., Harley, M. M. (1999): Ocimum: an overview of classification and relationships. In: Hiltunen R, Holm Y (eds) Basil: the genus Ocimum. Harwood, Amsterdam, 1-38.

Perez-Tornero, O., Egea, J., Vanoostende, A., Burgos, L. (2000): Assessment of factors affecting adventitious shoot regeneration from in vitro cultured leaves of apricot. in: Plant Sci. 158: 61-70. https://doi.org/10.1016/S01689452(00)00303-4

Phippen, W. B., Simon, J. E. (1998): Anthocyanins in basil. J. Agr. Food Chem. 46(5): 1734-1738. https://doi.org/10.1021/jf970887r

Phippen, W. B., Simon, J. E. (2000): Shoot regeneration of young leaf explants from basil (Ocimum basilicum L.). In Vitro Cellular - Developmental Biology-Plant, 36. 4: 250-254. https://doi.org/10.1007/s11627-000-0046-y

Ruzic, D. V., Saric, M., Cerovic, R., Culafic, L. (2003): Contents of macroelements and growth of sweet cherry rootstock in vitro. Biologia Plantarum 47: 463-465. https://doi.org/10.1023/B:BIOP.0000023897.84367.41
Ruzic, D. V., Vujovic, T. I. (2008): The effects of cytokinin types and their concentration on in vitro multiplication of sweet cherry CV. Lapins (Prunus avium L.). Horticultural Science (Prague) 35: 12-21. ISSN : 0862-867X

Saggiorato, A. G., Treiche, I., de Oliveira D., Cichoski A. J., Cansian R. L., (2012): Antifungal Activity of Basil Essential Oil (Ocimum basilicum L.): Evaluation in vitro and on an Italian-type Sausage Surface. Food Bioprocess Technol 5: 378. https://doi.org/10.1007/s11947-009-0310-z

Saha, S., Mukhopadhyay, M. K., Ghosh, P. D., Nath, D. (2012): Effect of Methanolic Leaf Extract of Ocimum basilicum L. on Benzene-Induced Hematotoxicity in Mice. Evid Based Complement Alternat Med. 2012; 2012: 176385. https://doi.org/10.1155/2012/176385

Saha, S., Dhar, T. N., Sengupta, C., Ghosh, P. D. (2013): Biological activities of essential oils and methanol extracts of five Ocimum species against pathogenic bacteria. Czech J. Food Sci. 31: 194-202. https://doi.org/10.17221/234/2012-CJFS

Sahin-Demirbag, N., Kendir, H., Khawar, K. M., Aasim, M. (2008): In vitro plant regeneration from Hungarian vetch (Vicia pannonica Crantz) using cotyledonary node explants. Biotechnol. Biotechnol. Eq. 22(4): 929-932. https://doi.org/10.1080/13102818.2008.10817581

Schmuelling, T., Rupp, H. M., Frank, M., Schaefer, S. (1999): Advances in Regulation of Plant Growth and Development, eds. Strnad, M., Pec P. \& Beck, E., Peres, Prague, 85-96. https://doi.org/10.1073/pnas.171304098

Simon, J. E., Quinn, J., Murray, R. G. (1990): Basil: A Source of Essential Oils. In: Janick, J., and J.E. SIMON (eds.), Advances in new crops. Timber Press, Portland, OR. 484-489.

Simon, J. E., Morales, M. R., Phippen, W. B., Vieira, R. F., Hao, Z. (1999): Basil: A Source of Aroma Compounds and a Popular Culinary and Ornamental Herb. In: Janick, J., ed, Perspectives on New Crops and New Uses. ASHS Press, Alexandria, 499-505. ISBN:0961502703

Srivastava, A. K. (1980): French Basil and its Cultivation in India. Farm Bulletin No 16, Central Institute of Medicinal and Aromaic Plants, Lucknow, 15.

Sutter, E. G. (1996): R.N. Trigiano, Gray (Eds), Plant Tissue Culture Concepts and Laboratory EXERCISES, CRC Press, New York, 11-25.

Tang, H., Ren, Z., Reustle, G., Krczal, G. (2002): Plant regeneration from leaves of sweet and sour cherry cultivarsSci. Hortic. 93: 235-244. https://doi.org/10.1016/S03044238(01)00328-4

Thorpe, T., Stasolla, C., Yeung, E.C., De Klerk, G.J., Roberts, A., George, E. F. (2008): The Components of Plant Tissue Culture Media II : Organic Additions, Osmotic and $\mathrm{pH}$ Effects, and Support Systems in: E.F. George, M.A. Hall, G.J. De Klerk (Eds.), Plant Propagation by Tissue Culture, Springer, 115-173. ISBN 978-1-4020-5005-3 (e-book) 